\title{
Critical Discourse Analysis of the Suicide Bombings at Three Churches in Surabaya on the News Published by Vice.Com
}

\author{
Rosalina Bilqisth ${ }^{1}$, Rachmat Kriyantono², Anang Sujoko³ \\ 1,2,3 University of Brawijaya, Malang, Indonesia \\ Email: r.bilqisth@gmail.com
}

\begin{abstract}
This study aims to reveal vice.com's discourse strategy in reporting the suicide bombings at three churches in Surabaya on 13 May 2018. This action caused many victims, namely 28 people died and 57 people were injured. The presence of mass media facilitates the search and acquisition of information by the public, especially with the emergence of online media. People tend to actively find out about what is going on and the existence of online media makes news very easily accessible to the public. Fairclough's critical discourse analysis model is applied to analyze news on vice.com media. Vice.com is an online media based in America-Canada. Vice.com first expanded to Southeast Asia and stopped in Indonesia. This study seeks to examine three levels of analysis in critical discourse analysis, namely: text, discourse practice, and sociocultural practice. Vice.com also has an independent position in exposing news without intervention from other parties. This is indicated by the vice.com editor who chooses a diction that tends to have neither negative nor positive connotations. In addition, 26 direct quotes were found in 4 news articles. At the text level, events are delivered coherently and clearly. Media vice.com does not seem to have an agenda to provoke the public regarding this issue because the news tends to only provide information regarding the number of victims. The situation conveyed is related to events, individuals, groups, situations, and others in the text. The role of language in the text used by vice.com editors is to educate audiences to understand the realities that actually happen easily. At the discourse practice level, the news production system has freedom in the news production process and there is no intervention from the capital owner to directly affect the reporting of the case. At the level of sociocultural practice, media vice.com puts forward a controlled, safe and peaceful situation in the socio-political area of Surabaya.
\end{abstract}

Keywords: Critical Discourse Analysis, Surabaya Bombing Tragedy, Media Construction.

\section{A. INTRODUCTION}

The phenomenon of terrorism and some forms of violence is a common phenomenon that occurs in almost all parts of the world. Junaid (2013) said that terrorism is a social phenomenon that exists and will always be faced by people around the world. On September 9, 2001 there was a bombing of the twin World Trade Center (WTC) buildings in New York, which at the same time served as a warning to the world community about the dangers of terrorism.

On May 13, 2018, there were suicide bombings at three churches in Surabaya, namely the Immaculate Santa Maria Catholic Church, the Surabaya Indonesian Christian Church (GKI), and the Surabaya Central Pentecostal Church (Damarjati, 2018). The modus operandi of this act of terror was carried out by a family who was divided into three locations where 
the terror acts were targeted. The perpetrators of this terror act are R. Dita Oepriarto and Puji Kuswati and their four children are known to be members of the Anshaarud Daulah congregation and the Anshaarud Tauhid Jamaah, which are the main supporters of ISIS (Damanik, 2018). This action caused many victims, as many as 28 people died and as many as 57 people were injured (Sarwanto, 2018). In addition to the fatalities and physical casualties, this act of terror certainly has a psychological impact on the people of the city of Surabaya, especially for the church members who were the target of the bombing.

The researcher chose one online media, namely Vice.com. Vice.com is an online media based in America - Canada. Vice.com first expanded into the Southeast Asia region and stopped in Indonesia, in November 2016 (Eka, 2016). According to Syahri, Kriyantono, \& Zulkarnain (2015) in general, media had different redaction policy, thus the decision to involve the news became their authority. This research need to know the discourse practice level and the news production system. The target audience for Vice.com is young people (Al Hafiz, 2019). Media ownership can affect the news that is published. According to Shoemaker \& Reese (1996), the construction of news content can be influenced by ideology, organization, and media ownership.

As it is known that Vice Indonesia is an extension of Vice Media, which is currently based in New York. In other words, the owner of Vice Media is from the West. Kriyantono \& Sa'diyah (2018) said that mass and online media is the modern reference source. In addition, Vice media also clearly said that they were media that came from the punk community. With such background conditions, the researcher is interested in revealing the influence of ideology in the Vice Indonesia (vice.com) news about the suicide bombings at three churches in Surabaya on May 13, 2018.

\section{B. LITERATURE REVIEW}

The phenomenon of terrorism can always attract the attention of the public, both nationally and internationally, considering the impact caused by acts of terrorism is evident. The impact of terrorism is felt directly by the area where terror acts occur, but this impact can quickly spread to other areas. Government need good strategy according phenomenon of terrorism. Communication strategy in normal and crisis situations should be pay attention to the public in order the public is not the party with the most suffer the consequences of the crisis (Kriyantono, 2015a; Kriyantono et al., 2017). This is in line with the opinion of Bartolucci (2012), the impact of terrorism can spread to several aspects of public life and individuals and groups. One of the roles of the mass media is to disseminate information about an issue to the public (Kriyantono, 2017). Mass media as a medium that is able to disseminate news to the wider community can be used as a tool for terrorists to spread panic, unrest, and fear. Giessmann (2002), argues that terrorists seek attention from the mass media as a medium capable of disseminating information to the public.

The formation of discourse in the mass media is strongly influenced by the ideology possessed by the mass media (Assidik \& Santoso, 2016). Opinions that develop in society are ultimately influenced by the mass media. This is proof that the mass media is not something neutral. Furthermore, Media organizations distribute messages that not only influence but it 
also reflects the culture of a society. So what happens in the media describe what is happening in the community (Kriyantono, 2007).

Eriyanto (2009) said that the mass media is not a free and neutral media or channel. Thus, the relationship between the political economy of the media in the text allows the linkage of language use to economic, political, social, and cultural processes in society. The political economy approach focuses on analyzing the relationship between the structure of the political economy, the dynamics of the media industry, and the ideology of the media itself. The attention of political economy research is directed at the ownership, control and operational power of the media market (Alfarabi, 2010).

\section{METHODS}

This study uses qualitative approach. This approach is used to explore more about a phenomenon that occurs (Kriyantono, 2012). Qualitative research is used to know and reveal the general idea of how television can construct (Pratomo \& Kriyantono, 2016). This study uses a critical paradigm to get an idea of how vice.com's discourse strategy in constructing the discourse of suicide bombing terrorism in three churches in Surabaya and to find out the hidden ideology behind its news production. The phenomenon of terrorism in this study will be discussed using critical discourse analysis. The main purpose of critical discourse analysis is to reveal the practice of power struggle in the text. Fairclough emphasizes that discourse in its reproduction will have a dominating relationship (Fairclough, 1995, p.24).

Fairclough maps critical discourse analysis in three dimensions, namely text, discourse practice, and sociocultural practice (Fairclough, 1995). The text is analyzed linguistically, which means paying attention to the vocabulary used, the semantics, and the grammar. Next, discourse practice. Discourse practice is a dimension related to the process of producing and consuming texts. Lastly, the sociocultural practice dimension relates to context. Such as situations, relationships with society, culture, and certain politics.

The researcher collects data from the vice Indonesia website, namely vice.com. This study collects data with the method of documentation. The data collected is news related to the suicide bombings carried out in three churches in Surabaya. Researchers found news texts about the discourse of reporting on the suicide bombing terror case that was carried out in three Surabaya churches on 13, 14, and 16 May 2018. The news texts were taken and then analyzed using the critical linguistic method.

\section{RESULTS AND DISCUSSION}

The use of language in reporting "Action of bomb terror in three locations" in daily Vice.com represents themes and characters through the selection of diction and selection of sources in direct quotations. During the period of May 2018, Vice.com published the news of "terror acts of bombs in three locations" 4 times, or over a period of 4 days, in the form of news headlines as follows:

1. Three churches in Surabaya experienced consecutive bomb explosions (13 May 2018)

2. Bomb Attack in Surabaya Shows Official Assumptions About JAD are Wrong (15 May 2018)

3. Complete Guide to Understanding the Series of Terror Actions in Indonesia in the Last Week (15 May 2018) 
4. Visited the Surabaya Bomber's Family Home Before the Church Bombing Attack (May 16, 2018)

The headlines used to describe the terrorist bombings in three locations mention the words bomb attacks, terror acts, and bomb attacks. Thus, this is reporting something that is threatening to society. The news that is being published in this daily does not focus on the name of the terrorist, this is indicated by the absence of a single text title that writes the name as "suspected terrorist". From the four news headlines, Vice.com wants to give readers a complete picture of how the incident occurred from the beginning to the information related to the family of the suspected terrorist.

Critical discourse analysis in Fairclough uses news sources as the basis for text analysis. In voicing his inspiration for accuracy and neutrality, he uses direct quotes from figures who are sources. In the content of the text, it tends to contain more quotes from various parties, both the government and the National Police as a government agency that handles terrorism cases in Indonesia, and also includes witnesses and CCTV footage.

Based on the results of data analysis, 26 direct sentences were found in 4 news articles. This number means the number of direct quotes from credible sources compared to media opinions given in news articles.

From some of the examples above, it can be seen that Vice.com chooses more varied sources to maintain the neutrality of the news. There is a tendency of 26 to favor those who provide information related to the bomb tragedy in three locations in their reporting, as quoted from the Director of Communication and Information of the State Intelligence Agency (BIN), terrorism observer Solahudin from the University of Indonesia, National Police Chief Tito Karnavian at the Regional Police Headquarters,, Former high-ranking JI military wing Nasir Abbas.. This is understandable because the case being discussed is terrorism so that a credible source is the party providing information related to the bomb tragedy.

Mass media as a means of communication and information can disseminate information en masse and can be accessed by the public in bulk either in print or through internet technology as online information. The information provided by the media is very possible in influencing changes in people's mindsets and behavior (Dj.2018)

Vice.com raises the case of bombings at three locations suspected of being terrorists in May 20184 times. Dita is a suspected terrorist who was shot by officers. News is stated by William S. Maulsby in $\mathrm{Dj}$ (2018) as part of a true and impartial narrative of facts, has important and new meaning and can attract the attention of readers.

The number of news texts displayed by vice.com is not so much compared to other media. This indicates that the news did not pay attention to the public in a short period of time because it was published at the same time, but with a small number of articles. The interesting thing about the text production by vice.com is how this media positions itself as an outsider and maintains its neutrality in reporting.

Discourse is the flexibility of language use, taking meaning in context for the wearer, and feeling purposeful, meaningful, and related (Cook, 1994). Crystal (in Nunan, 1993) states that discourse is a continuous range (especially spoken language), which is longer than a sentence, often a coherent unit, such as an argument, joke or narrative.

The results showed that the linguistic aspect of the text, the selection of sources in direct quotations used by the media had placed the theme of reporting on the terrorist bombing in three locations as public discourse in responding to the case. The involvement of the news sources cited tends to be direct access from the Police Headquarters for news clarification, rarely using the police at lower levels. This is because for terrorism cases, the 
authority to provide information is only at the Headquarters level. The second level in Fairclough's CDA is the discourse practice of reporting "the bomb terror acts in three locations". Vice.com's daily vision is to serve as the main, trusted information provider with professional business management.

Based on the results of his analysis, it can be revealed that Vice Indonesia chose several dictions that tend to be more neutral in the news. Vice.com also has an independent position in exposing news without intervention from other parties. It seems to help create a conducive and peaceful situation in informing the public of the news.

\section{E. CONCLUSION}

Critical discourse analysis using the Fairclough method covers three domains, namely aspects of the text, sociocultural practice, and sociocultural practice. Vice.com chose to be neutral in delivering news of the terrorist bombings in three locations by choosing a diction that tends to have neither negative nor positive connotations, as indicated by the discovery of 26 direct quotes in 4 news articles. Vice.com is advised to maintain its function as a neutral social control media so that the objectivity aspect of the media is maintained in every reporting process. Researchers get the following conclusions:

1. At the text level, events are delivered coherently and clearly. Media vice.com does not seem to have an agenda to provoke the public regarding this issue because the news tends to only provide information regarding the number of victims. The situation conveyed is related to events, individuals, groups, situations, and others in the text. The role of language in the text used by vice.com editors is to educate audiences to understand the realities that actually happen easily. Balanced reporting is characterized by the number of direct sentences. Articles can be a reference for readers regarding the chronology of cases.

2. At the level of discourse practice, the news production system has freedom in the news production process and there is no intervention from the owner of capital to directly affect the reporting of the case.

3. At the level of sociocultural practice, media vice.com puts forward a controlled, safe and peaceful situation in the socio-political area of Surabaya. Vice.com prefers to implement a social control function over the news it chooses and does not make the case of bomb terror acts in three locations as media opinion, but follows the case process and provides objective information to the public.

\section{REFERENCES}

1. Al Hafiz, M. P. (2019). Cara Vice Indonesia Bangun Pasar Pembacanya. Retrieved from https://marketeers.com/cara-vice-indonesia-bangun-pasar-pembacanya/

2. Alfarabi. (2010). Kajian Komunikasi Kritis Terhadap Ekonomi Politik Media. Jurnal Idea Fisipol UMB, 84 (17), 1-4.

3. Assidik, G. K., \& Santoso, W. (2016). Citra Publik Presiden Republik Indonesia pada Pemberitaan di Harian Suara Merdeka, Tabloid Tempo, dan Harian Republika: Kajian Analisis Wacana Kritis Model Norman Fairclough. Jurnal Seloka: Pendidikan Bahasa dan Sastra Indonesia, 5 (2), 201-215.

4. Damanik, M. J. (2018). 5 Fakta Tak Terduga Pelaku Bom di Surabaya, Tinggal di Rumah Rp 1 M Lebih. Retrieved from https://www.idntimes.com/news/indonesia/margith-juita- 
damanik/5-fakta-tak-terduga-pelaku-bom-di-surabaya-tinggal-di-rumah-rp-1-m$\underline{\text { lebih/full }}$

5. Damarjati, D. (2008). Detail Rentetan Bom 2 Hari di Surabaya dan Sidoarjo. Retrieved from https://news.detik.com/berita/4020228/detail-rentetan-bom-2-hari-di-surabaya-dansidoarjo

6. Eka, R. (2016). Media Muda VICE Hadir di Indonesia untuk Ekspansi Pertamanya di Asia Tenggara. Retrieved from https://dailysocial.id/post/media-muda-vice-hadir-diindonesia-untuk-ekspansi-pertamanya-di-asia-tenggara

7. Eriyanto. (2001). Analisis Wacana: Pengantar Analisis Teks Media. Yogyakarta: LKiS.

8. Fairclough, N. (1995). Language and Power. London \& New York: Longman.

9. Giessmann, H. I. (2002). Media and the Public Sphere: Catalyst and Multiplier of Terrorism?. Media Asia Communication Quarterly, 20 (3), 134-136.

10. Junaid, H. (2013). Pergerakan Kelompok Terorisme dalam Perspektif Barat dan Islam. Jurnal Pendidikan Agama Islam, 8 (2), 118-135.

11. Kriyantono, R. (2012). Teknik Praktis Riset Komunikasi. Jakarta: Prenada Media.

12. Kriyantono, R. (2007). Pemberdayaan Konsumen Televisi Melalui Keterampilan Media Literacy dan Penegakan Regulasi Penyiaran. Jurnal Penelitian Komunikasi, Media Massa dan Teknologi Informasi, 10(21).

13. Kriyantono, R. (2015a). Public Relations, Issue \& Crisis Management: Pendekatan Critical Public Relations, Etnografi Kritis \& Kualitatif. Jakarta: Kencana.

14. Kriyantono, R. (2017). Teori public relations perspektif barat $\mathcal{E}$ lokal: Aplikasi penelitian dan praktik. Jakarta: Kencana Prenada.

15. Kriyantono, R., \& Sa'diyah, H. (2018). Kearifan Lokal dan Strategi Komunikasi Public Relations di BUMN dan Perusahaan Swasta.

16. Pratomo, D. A., \& Kriyantono, R. (2016). The power of media effect: Construction television as media for anti-corruption education in Indonesia. KKU International Journal of Humanities and Social Sciences, 6(1), 1-9.

17. Sarwano, A. (2018). Korban Tewas Bom Surabaya 28 Orang, 57 Orang Luka. Retrieved from https://www.cnnindonesia.com/nasional/20180514194201-12-298164/korban-tewas-terorbomsurabaya-28-orang-57-luka

18. Shoemaker, P. J., \& Reese, S. D. (1996). Mediating the Message: Theories of Influences on Mass Media Content. New York: Longman.

19. Syahri, M. A., Kriyantono, R., \& Nasution, Z. (2015). An explanative study on the different perceptions of journalists toward media relations of governmental and private public relations. Asian Journal of Humanities and Social Sciences, 3(1), 36-48. 